\title{
ЭКОНОМИЧЕСКИЕ И ПОЛИТИЧЕСКИЕ КОНКУРЕНТЫ РОССИИ В РУССКОЙ АМЕРИКЕ В НАЧАЛЬНЫЙ ПЕРИОД ДЕЯТЕЛЬНОСТИ РОССИЙСКО- АМЕРИКАНСКОЙ КОМПАНИИ (1799-1818 ГГ.) И РЕАЛЬНОСТЬ ЗАВЕРШЕНИЯ ПРОЕКТА «РУССКАЯ АМЕРИКА» В 1818 Г.
}

\author{
(c) 2021 Будович Юлия Ивановна \\ доктор экономических наук, доцент, профессор Департамента экономической теории \\ Финансовый университет при Правительстве Российской Федерации, Россия, Москва \\ E-mail: JBudovich@fa.ru \\ ORCID: https://orcid.org/0000-0001-8691-947X

\section{(c) 2021 Будович Маргарита Сергеевна} \\ кандидат экономических наук, доцент Департамента экономической теории, \\ Финансовый университет при Правительстве Российской Федерации, Россия, Москва \\ E-mail: MSBudovich@fa.ru \\ ORCID: https://orcid.org/0000-0002-7234-1408
}

В статье доказывается, что в период, который был необходим русским частным пушным компаниям и товариществам для заселения оставшейся незаселенной русскими территории Русской Америки, а именно в 1799-1818 гг., что могло произойти в том случае, если бы русский пушной бизнес в Северной Америке не был слит в монопольную Российско-Американскую компанию в 1799 г., существовали исключительно благоприятные условия как для занятия русскими пушными компаниями всей территории Русской Америки - с точки зрения конкуренции со стороны англо-американских пушных компаний, так и для официального присоединения соответствующих земель к России - с точки зрения отношения ее территориальных конкурентов в Северной Америке к праву присоединения к странам незанятых европейцами земель по праву первозаселения.

Ключевые слова: Русская Америка, Российско-Американская компания, нефинансовая форма собственности, поселенческая активность, поселенческая экспансия.

В опубликованной в настоящем номере журнала «Экономические науки» статье К.Н.Лебедева «Провал проекта «Русская Америка» и зависимость поселенческой активности русского колониального пушного бизнеса от формы собственности» доказывается, что, если бы частные пушные компании и купеческие товарищества, участвовавшие в реализации проекта царского правительства «Русская Америка (РА)», не были бы слиты в монопольную пушную Российско-
Американскую компанию (РАК), то, при прочих равных условиях, оставшаяся незаселенной русскими территория РА была бы целиком охвачена пятном русских постоянных поселений уже в 1818 г., и Россия могла бы ее официально присоединить к себе по праву первозаселения. При этом К.Н.Лебедев исходит из двух предположений. 1-м является то, что поселенческая экспансия русского пушного бизнеса в Северной Америке (СА) сохраняет прежнюю (как в 1742-1799 г.) скорость. 2-м является то, что в случае более раннего появления в каких-то местах РА постоянных поселений пушного конкурента русских, которым выступала британская Северо-Западная компания (СЗК), созданная, как и РАК, в форме акционерного общества (AO), русские пушные компании, имеющие нефинансовую форму собственности, как более эффективные, победили бы его в конкурентной борьбе за пушнину, предлагая индейцам за нее больше товаров, чем менее эффективная СЗК, в связи с чем поселения СЗК отошли бы к русским или оказались заброшенными. В нашей статье «Провал проекта «Русская Америка» и погоня за прибылью Российско-Американской компании», опубликованной в данном номере журнала «Экономические науки», было показано, что сама поселенческая активность пушной компании является фактором ее эффективности. Целью настоящей статьи является показать, что русским частным пушным компаниям в борьбе за туземную пушнину не могла противостоять и британская пушная Компания Гудзонова залива 
(КГЗ), также созданная в форме АO, если бы ее привлекли в РА поселенческие успехи русских, подтвердить более низкую эффективность акционерной СЗК, сделав это на основе анализа поселенческой активности, присущей данным пушным AO, показать, что до 1818 г. включительно существовали абсолютно благоприятные политические условия для объявления земель РА российскими территориями, чем подтвердить сделанный К.Н.Лебедевым вывод о том, что если бы не ошибочное решение царского правительства о слитии пушного российского бизнеса в СА в монопольную РАК, то РА вполне могла быть целиком (а не только в части Аляски) присоединена к России еще в 1818 г. Соответствующий вопрос в отношении КГЗ поднимается в связи с тем, что она могла попытаться помешать заселению русскими РА, так как по близости с территорией Юкон (приблизительно соответствовала территории современной канадской провинции Юкон), входящей в РА, восточнее ее на р. Маккензи уже с 1805 г. функционировал пушной пост КГЗ [4], находившийся на 66 с.ш. и 128 з.д. [24]

Предварительно, заметим, что мысль о неэффективности торговых колониальных АО, обладающих (как КГЗ и РАК) или не обладающих (как СЗК) привилегиями, по сравнению, в частности, с полными купеческими товариществами (т.е. предприятиями, в непосредственном управлении которыми принимают участие все их собственники), действующими в колониях, высказывал еще А. Смит в «Богатстве народов» (1776). Как писал А. Смит, АО, созданные для внешней торговли, редко выдерживают конкуренцию частных купеческих товариществ, редко имеют успех без привилегий, но зачастую не имеют его и с привилегиями, без исключительных привилегий они, как правило, торговлю расстраивают, а при исключительных привилегиях - и расстраивают ее, и стесняют. Объяснял А.Смит такую ситуацию, как и теория нефинансовой экономики, теми же болезнями управления АO, вызванными финансовым способом приобретения в собственность имущества компании ее топ-менеджментом. Как отмечал А.Смит, директора АО заведуют в основном чужими деньгами, в связи с чем от них невозможно ожидать той неусыпной осторожности, которую в управлении своим капиталом проявляют участники торгового товарищества, и расточительность и небрежность всегда наблюдаются в управлении делами АО [20].

Этот вывод, как А. Смита, так и теории нефинансовой экономики, подтверждается анализом поселенческой активности КГЗ и СЗК - дело в том, что, как отмечается в нашей статье, указанной выше, поселенческая активность пушной компании выступает важным фактором ее эффективности, так как с этой активностью связана диверсификация пушной линейки, диверсификация бизнеса компании в целом, а также развитие собственного производства всего необходимого для обеспечения ее деятельности, позволяющие обеспечить бескризисное функционирование пушной компании при наступлении разнообразных неблагоприятных обстоятельств, например, такого, как выход из моды бобровых шапок и шуб, который имел место 1840-х гг. [13], для пушной компании, специализирующейся на заготовке бобровых шкур. Обратим внимание на то, что поселенческая активность пушной компании, специализирующейся на добыче шкур сухопутных животных, каковыми были британские КГЗ и СЗК, состоит в движении ее постоянных поселений вглубь страны по водным (речным и озерным) путям.

Рассмотрим поселенческую активность КГЗ. КГЗ в 1670 г. королевской хартией было дано монопольное право торговли в морях, реках, озерах, фьордах и т.д., лишь бы они лежали у входа в Гудзонов пролив, а также во всех землях на их побережье, если только они не находятся во владении других подданных короны или подданных другого христианского государства или государя [7]. Гидрографический бассейн Гудзонова зал. получил название «Земля Руперта» в честь принца Руперта, 1-го губернатора данной земли, которая включала территории современных канадских провинций: Манитоба - почти всей, Саскечеван - большей части, Альберта и Нунавут - южных частей, Онтарио и Квебек северных частей, а также современных штатов США: Миннесота и Северная Дакота - их частей [6]. К 1682 г. у КГЗ были открыты фактории в устьях рек Руперт, Олбени, Хейс, Нельсон и Северн [7], т.е. все торговые посты КГЗ через 12 лет после учреждения компании (1682-1670) все еще находились только по берегам Гудзонова зал. Очевидно, поселенческой экспансии во внутренние районы должно предшествовать их исследование (а у эффективной пушной компании - почти совпадать с ней). 1-я попытка исследовать внутренние земли, лежащие за Гу- 
дзоновым зал., была предприняты КГЗ только в 1691-1692 гг. - в эти годы предположительно по p. Нельсон совершил путешествие внутрь материка Генри Келси [7]. При этом форт Нельсон был построен еще в 1670 г. [1] Таким образом, между основанием поселения на берегу и лишь чисто исследовательским походом из него внутрь материка у КГЗ прошел целый 21 год! (1691-1670). Эту скорость проникновения внутрь материка пушной компании, занимающейся мехом сухопутных животных, созданной в форме AO, не сравнить с таковой русской пушной компании купца П.С. Лебедева-Ласточкина (КЛ), находившейся в единоличном владении последнего, т.е. имевшей нефинансовую форму собственности. КЛ, вследствие угрозы истребления морского зверя в районе ее промыслов у южного берега Аляски, решила диверсифицировать свою пушную линейку, занявшись добычей шкур сухопутных животных. Построив в 1792 г. постоянное поселение на севере зал. Кука, сотрудники КЛ в том же году направились на северо-запад и проникли вглубь материка на оз. Илиамна, где также основали крепость, и в том же году (25 декабря 1792 г.) из этой крепости продолжила путь на северо-запад экспедиция промышленника КЛ Василия Иванова, которая дошла до р. Юкон и даже до южного побережья зал. Нортона, возвратившись назад 17 апреля 1793 г. [14] Пушная компания с нефинансовой капитальной системой, таким образом, приступила к исследованию внутренних земель сразу же после того, как основала поселение на побережье, да еще и в ходе этот исследования основала крепость в глубине материка.

Такая поселенческая медлительность КГЗ была для нее нормой и, естественно, не могла не отмечаться современниками и исследователями ее деятельности. Путешествие Г. Келси характеризуется как «признак пробуждения Компании Гудзонова залива от сладкого сна на берегах залива» [7]. При этом пробуждение наступило нескоро. Этому пробуждению КГЗ в определенное время могла мешать разгоревшаяся за земли вокруг Гудзонова зал. борьба с англичанами французов, пославших в 1686 г. в Гудзонов зал. экспедицию и даже завладевших торговыми постами КГЗ, конец которой был положен Утрехтским миром [7]. По соответствующему англофранцузскому договору (от 11 апреля 1713 г.) земли вокруг Гудзонова зал. перешли от Франции к Англии [22], и после этого политические обсто- ятельства уже не могли блокировать реализацию территориальных устремлений КГЗ (если бы таковые были). Однако следующее, опять чисто исследовательское путешествие было предпринято КГЗ только в 1755 г., когда вглубь материка по водным путям из фактории Йорк, находившейся в устье р. Хейс, осуществил свой поход Антони Хендри [7], т.е. КГЗ после заключения Утрехтского мира проспала сладким сном на берегах залива еще 42 года (1755-1713). Аналогичное путешествие совершил Метью Кокинг в 1772 г., т.е. еще через 17 лет (1772-1755), которое также не закончилось устройством факторий внутри страны. КГЗ решила оторваться от берегов только в 1774 г. под воздействием конкурентов из Восточной Канады, когда А.Хендри основал на Нижнем Саскечеване пост Камберленд-Хаус [7]. Это произошло через 104 года (1774-1670) после обоснования КГЗ на побережье!

И это еще не все. Подобно тому, как государственной обязанностью РАК было присоединение к России новых земель, таковой у Компании Гудзонова залива был поиск Северо-западного прохода. Но, основанная в 1670 г., КГЗ соответствующие географические исследования начала только в 1742 г. после того, как в Англии стала подниматься волна недовольства из-за того, что КГЗ, получившая привилегии потому, что должна была в интересах государства заниматься поисками Северо-западного прохода, не выполняет этой функции [7]. Таким образом, КГЗ приступила к исполнению своей государственной функции только через 72 года после своего основания (1742-1670)! Очевидно, на фоне КГЗ деятельность РАК выглядит значительно успешнее. Она уже в 1812 г., т.е. всего лишь через 13 лет после своего учреждения в 1799 г. (1812-1799), основала на побережье Калифорнии колонию Росс (в отличие от компании, промышляющей сухопутным зверем, поселенческая активность пушной компании, промышляющей морским зверем, каковой была РАК, заключается в движении не вглубь материка, а по его побережью и близлежащим островам), а в 1815-1817 гг. делала реальные шаги по присоединению к России Гавайских о-вов (см. ниже), в 1824 г.- Калифорнии - усилиями приехавшего в Форт-Росс декабриста Д.И.Завалишина [12], т.е. занялась выполнением государственных обязанностей значительно быстрее после своего учреждения, чем КГЗ.

СЗК была создана в 1783 г., и с самого начала 
на службе у нее находился Александр Маккензи, задачей которого было руководство освоением западных территорий (точнее, всего северозапада СА. - примеч. авт.). Штаб-квартирой СЗК изначально был Гранд Портидж, штат Миннесота, США, находящийся на берегу оз. Верхнее [18] на $47^{\circ}$ с.ш. и $89^{\circ}$ з.д. [3] СЗК, также как и КГЗ, в начальный период своего функционирования был присущ «сладкий сон на берегах», только в данном случае крупнейших североамериканских озер и в значительно меньших масштабах (последнее, очевидно, потому, что СЗК создавалась не на пустом месте, а для борьбы с КГЗ в сфере мехоторговли [18], т.е. она изначально должна была быть более быстрой, чем неповоротливая КГЗ). Создание в 1888 г., т.е. через 5 лет после основания СЗК (1888-1883), по указанию А. Маккензи на оз. Атабаска на самом северовостоке современной канадской провинции Альберта форта Чипевиан [15] на $58^{\circ}$ с.ш. и $111^{\circ}$ 3.д. [28] нельзя рассматривать как прорыв в закреплении за собой северо-запада СА, поскольку он означал лишь выход СЗК на север за Землю Руперта, на которой монопольно распоряжалась КГЗ, т.е. на очередную исходную позицию для поселенческой экспансии, что соответствовало продолжению сна на берегах.

В 1795 г. сотрудник СЗК Жак Вье основывает пост на месте, где затем появится американский г. Милуоки [18]. Милуоки находится на западном берегу оз. Мичиган на $43^{\circ}$ с.ш. и $87^{\circ}$ 3.д. [8], так что основание здесь мехового поста является не только продолжением топтания на берегу, но и движением поселений СЗК не на запад южнее Земли Руперта, а затем по всему северо-западу СА, что соответствовало смыслу существования компании, отраженному в ее названии, а на юго-восток. В 1794 г. по договору между США и Великобританией территория, на которой находился Гранд Портидж, перешла под американский контроль, а так как в данном пункте осуществлялся обмен мехами и припасами с заготовителями меха, возникала проблема уплаты американских налогов. Но операции из Гранд Портиджа переносятся лишь в 1803 г. на территорию современной канадской провинции Онтарио в Форт-Уильямс [18], построенный в речном устье на берегу того же оз. Верхнее на $48^{\circ}$ с.ш. и $89^{\circ}$ з.д. [26]

Только в 1789 г., т.е. через 6 лет после основания СЗК (1789-1783), А. Маккензи совершает поход по северо-западу СА к Северному Ледови- тому океану, и то - с чисто исследовательскими целями [15], как это часто практиковалось у КГЗ (см. выше). За склонность к чистому исследованию на севере СА СЗК расплачивается тем, что в 1805 г. на р. Маккензи, открытой А. Маккензи, обосновывается КГЗ (см. выше). Только в 1793 г., т.е. через 10 лет после основания СЗК (17931783), А. Маккензи совершает поход, опять только чисто исследовательский, к Тихому океану, открыв по пути Внутреннее плато между Передовым и Береговым хребтами Скалистых гор и верхний участок течения р. Фрейзер [15]. Лишь в 1805 г., т.е. через 22 года после основания СЗК (1805-1783), другой сотрудник СЗК, Саймон Фрезер, идя по стопам А. Маккензи, в ходе дальнейшего исследования р. Фрейзер приступает к формированию на северо-западе Внутреннего плато (в районе 54-й параллели) на реках и мелких озерах пятна постоянных поселений СЗК из 5 постов, закрепившись тем самым на территории Новая Каледония [9], входящей в состав РА. Именно это событие следует считать выходом СЗК из спячки на берегах. Самым западным из них в 1805 г. был форт Маклеод на оз. Маклеод на $54^{\circ}$ с.ш. и $123^{\circ}$ з.д. [10]. Самым близким к пятну поселением на берегах крупнейших озер был форт Чипевиан, основанный в 1788 г. и находившийся на $111^{\circ}$ з.д. (см. выше). Таким образом, поселения СЗК продвигались на запад со скоростью $0,76^{\circ}$ в год ((124-111)/(1805-1788)). В вышеуказанной статье К.Н Лебедева подсчитано, что пятно постоянных поселений русских в ходе освоения новых пушных угодий множеством пушных предприятий с нефинансовой формой собственности двигалось на восток по Сибири со скоростью $0,85^{\circ}$ в год, а по СА $-1^{\circ}$ в год. Однако поселенческая активность русских пушных компаний с нефинансовой формой собственности в Сибири и на северо-западе СА отличалась не только более высокой скоростью поселенческой экспансии, чем соответствующая активность СЗК, но и ее качественно иным уровнем - она представляла собой распространение сплошной полосы постоянных поселений, тогда как у СЗК распространение поселений в соответствующем направлении имело лишь точечный характер, что не позволяло СЗК надежно закрепиться на пройденном пути в направлении Новой Каледонии. Такой же точечный характер имело и распространение постоянных поселений РАК на юг по северо-западному побережью СА -поселение Росс, основанное РАК в Калифорнии (см. выше), 
и было точечным поселением

Слабость поселенческой активности акционерной СЗК по сравнению с пушными компаниями с нефинансовой формой собственности подтверждается и анализом скорости формирования отдельных сетей постоянных поселений. Экспедиция С. Фрейзера создала сеть, правда, из 5 поселений в Новой Каледонии за осень $1805-$ лето 1807 г. [29], т.е. за 8 сезонов, тогда как экспедиция Тихоокеанской пушной компании (ТПК) Дж.Дж.Астора, высадившись в устье р. Колумбия, создала свою сеть из 3 поселений в стране Орегон (в Астории) за весну - осень 1811 г. [23], т.е. за 3 сезона. Да и по широте сеть СЗК раскинулась на $3^{\circ}$ (на $121-124^{\circ}$ з.д. [9; $\left.\left.17 ; 25 ; 27 ; 30\right]\right)$, тогда как сеть ТПК - на 4 (см. нашу вышеуказанную статью). Важно отметить, что ТПК, рассматриваемое здесь как предприятие с нефинансовой формой собственности, также было создано в форме АО, однако весь его капитал, разделенный на 100 акций, был полностью профинансирован Дж.Дж. Астором [21], т.е. ТПК фактически выступала частной купеческой компанией. Это как раз тот часто отмечающийся в наших работах случай, когда реальные отношения собственности не совпадают с юридическими, как это было, например, в нашей стране при введении с марта 1917 г. после Февральской революции 1917 года на государственных и акционерных предприятиях Петрограда стихийного рабочего контроля, вследствие чего соответствующие предприятия фактически превращались в производственные кооперативы, демонстрируя, как предприятия с нефинансовой формой собственности, большую эффективность, чем была до введения на них рабочего контроля [2, с. 481-482].

Таким образом, анализ поселенческой активности пушного колониального бизнеса, организованного в форме $\mathrm{AO}$, по сравнению с таковой пушного колониального бизнеса с нефинансовой формой собственности, подтверждает большую эффективность последнего и, следовательно, вывод о том, что ни КГЗ, ни СЗК не смогли бы помешать заселению русскими оставшейся незаселенной ими территории РА даже в случае, если бы постоянные поселения КГЗ и СЗК появились в каких-то ее частях раньше постоянных поселений русских купеческих колониальных пушных компаний.

В статье К.Н.Лебедева отмечается, что американская пушная ТПК не смогла бы закрепиться в 1811 г. в бассейне р. Колумбия, так он был бы занят русскими пушными компаниями еще в 1810 г., а бизнес вне этого региона, например южнее того места, до которого в 1811 г. дошла полоса русских поселений, ТПК не интересовал. Важно отметить, что последующие 1812-1814 гг. были абсолютно неблагоприятными для поселенческой экспансии в стране Орегон англоамериканских пушных компаний, так как в этот время шла англо-американская война (см. выше), а в 1814 г., т.е. к году ее окончания, как отмечает К.Н.Лебедев, русские постоянные поселения уже вышли бы на южную границу страны Орегон.

Важно отметить, что испанцев пушной бизнес принципиально не интересовал, так что никакой конкуренции русскому пушному бизнесу на территории Калифорнии со стороны испанского бизнеса составлено бы не было.

В 1799-1818 гг. для присоединения всей РА к России по Калифорнию включительно существовали и исключительно благоприятные политические условия. Дело в том, что в этот период времени реальные территориальные конкуренты России в СА, которые могли бы политическими и даже военными средствами помешать присоединению к России земель РА, уважали право присоединения незанятых европейцами земель на основе первозаселения. Об этом лучше всего говорит то, что США и Великобритания в подписанных с Россией в 1824 и 1825 г. соответственно конвенциях, регулирующих взаимные права стран на северо-западном побережье СА, официально признали российской территорией Аляску (с Алеутскими островами) [11], в пределах которой и оставалось на то время пятно русских постоянных поселений в СА, чем и подтвердили свое согласие с вышеуказанным правом в отношении России.

Следует отметить, что в 1799-1818 гг. в США, которые в тот период времени превращались в главного территориального конкурента России в СА, Россия рассматривалась как мощнейшая мировая держава, уже давно законно и прочно обосновавшаяся на северо-западе СА, возможно, считавшемся продолжением Сибири, и намеченной экспансии которой невозможно противостоять. Об этом говорит то, что отношение к России как к полновластной хозяйке севера тихоокеанского региона, в том числе северозападной части СА, которой она должна была стать по царскому плану, сохранялось в правительственных кругах США еще в начале 1820-х 
гг., уже очевидным образом вопреки реальному положению дел. Это подтверждает заслушанный в январе 1821 г. в Конгрессе США доклад специальной комиссии, посвященной результатам экспедиции, посланной США для занятия с материка р. Колумбия, в связи с чем границы американских владений приближались к русским прибрежным поселениям, основным выводом которого было то, что США упустили возможность полного овладения соответствующим краем (очевидно, страной Орегон! - примеч. авт.). При этом в данном докладе Россия определяется как мощная сила, стремящаяся к мировому господству, от страшного могущества которой не ограждаются даже владения в СА испанского короля, как страна, владеющая соответствующими территориями по праву в силу предпринятых ею неслыханных предприятий, в которых она не щадила ни издержек, ни труда, ни забот, с миллионом войска ограждающая свои города, крепости, магазины, торговлю, возникшие в данном крае, которая не позволит что-либо у нее отнять, обладающая такими важнейшими стратегическими пунктами на побережье, как Новоархангельск (около $57^{\circ}$ с.ш.) и Бодего (около $38^{\circ}$ с.ш.), и владеющая одним из Сандвичевых (Гавайских.- примеч. авт.) о-вов, что не только дает ей возможность удержать имеющиеся позиции, но и повелевать всей северной частью Тихого океана. В докладе также отмечалось, что активность России с каждым днем увеличивается [11]. Понятно, что такое представление о положении России в регионе на начало 1820-х гг. уже не соответствовало действительности. Россия, в результате деятельности на Гавайских о-вах в 1815-1817 гг. сотрудника РАК Шеффера, действительно, была близка к овладению Гавайскими о-вами (в частности, РАК были приобретены или получены в собственность от туземных правителей многие земли на островах, на которых были разведены плантации и построены дома, например на о. Овагу, где, кстати, уже были плантации американских купцов братьев Виншеп, туземный владетель части Гавайских о-вов Томари 21 мая 1816 г. официально принял русское подданство, на Гавайских о-вах было построено несколько русских крепостей - Александровская, Елизаветинская и Барклая), но в 1817 г. сами американцы (американские купцы) вытеснили Шеффера с этих о-вов [12].

Представляется, что в 1799-1818 гг. с присоединением к России северо-западного побережья СА по Калифорнию включительно смирилась бы и Испания, причем его неизбежность, по нашему мнению, была признана ими еще в 1780-е гг. или даже раньше. Как выясняется, русские купцы и промышленники уже в 1740-1750-е гг. занимались заготовкой шкур морского зверя в северной части побережья Верхней Калифорнии, но испанцы, обнаружив это, закрепились или решили закрепиться, путем строительства на побережье постоянных испанских поселений, только в южной части побережья Верхней Калифорнии (ее южная граница находилась между 32-й и 33-й параллелями [16]). В 1769 г. отправленная по распоряжению губернатора Мексики Гаспара де Порто экспедиция высадилась на берегу зал. Сан-Диего и основала 1-е испанское поселение с таким же названием [5] на самом юге побережья Верхней Калифорнии. В 1776 г. испанцами был основан Сан-Франциско [19], на чем продвижение испанских постоянных поселений на север по побережью Верхней Калифорнии прекратилось, возобновившись только в 1819 г., когда чуть севернее Сан-Франциско, с тем, чтобы помешать движению русских поселений на юг от Форт-Росса, было построено ранчо Сонома [12].

Таким образом, в 1-е 20 лет (1799-1818 гг.) деятельности РАК существовали исключительно благоприятные условия для занятия русскими всех остальных земель РА (кроме уже занятой Аляски) и присоединения их к России с точки зрения как конкуренции со стороны англоамериканского пушного бизнеса, так и отношения государств-территориальных конкурентов к праву присоединения к странам незанятых европейцами территорий на основе их первозаселения.

\section{Библиографический список}

1. Битва при Гудзоновом заливе (1697г.) / Википедия. URL: https://ru.frwiki.wiki/wiki/Bataille_de_la_ baie_d\%27Hudson_(1697) (дата обращения: 06.09.2021).

2. Будович Ю.И., Будович М.С. Государственно-капиталистический и кооперативный пути перехода к коммунизму и партийная программа // Экономические науки. 2020. № 12 (193). С. 479-487. DOI: 10.14451/1.193.479. 
3. Гранд Портидж, Миннесота / Википедия. URL: https://en.wikipedia.org/wiki/Grand_Portage,_Minnesota (дата обращения: 12.09.2021).

4. Гринев А. В. На берегах Медной реки: индейцы атна и русские в 1783-1867 г.г. / Насельники дикого севера. URL: http://beaverlodge.wmsite.ru/etnografija/avgrinev-20259/ (дата обращения: 20.08.2021).

5. Денежкина М., Марчант Т. История Калифорнии от древних времен до американской аннексии / Миртесен. 14.03.2014. URL: https://s30556663155.mirtesen.ru/blog/43972272253/Istoriya-Kalifornii-ot-drevnih-vremendo-amerikanskoy-anneksii (дата обращения: 08.08.2021).

6. Земля Руперта / Википедия. URL: https://ru.wikipedia.org/wiki/\%D0\%97\%D0\%B5\%D0\%BC\%D0\%BB\%D1\%8F_\% D0\%A0\%D1\%83\%D0\%BF\%D0\%B5\%D1\%80\%D1\%82\%D0\%B0 (дата обращения: 13.09.2021).

7. Исследования англичан со стороны Гудсонова залива / База знаний. URL: http://proznania.ru/books. php/?page_id=1073 (дата обращения: 24.07.2021).

8. Милуоки / Википедия. URL: https://ru.wikipedia.org/wiki/\%D0\%9C\%D0\%B8\%D0\%BB\%D1\%83\%D0\%BE\%D0\%B A\%D0\%B8 (дата обращения: 12.09.2021).

9. Новая Каледония (Канада) / Ow. URL: https://ru.abcdef.wiki/wiki/New_Caledonia_\%28Canada\%29 (дата обращения: 28.08.2021).

10. Озеро Маклеод - McLeod Lake / Ow. URL: https://ru.abcdef.wiki/wiki/McLeod_Lakehttps://ru.abcdef.wiki/wiki/ McLeod_Lake (дата обращения: 28.08.2021).

11. Окунь С.Б. Российско-американская компания. III. Начало деятельности Российско-Американской компании / www.booksite.ru. URL: https://www.booksite.ru/fulltext/russ_america/05_15_3.html (дата обращения: 26.08.2021).

12. Окунь С. Б. Российско-американская компания. VI. Поселение «Росс» в Калифорнии / www.booksite.ru. URL: https://www.booksite.ru/fulltext/russ_america/05_15_4.html (дата обращения: 26.08.2021).

13. Орегонский путь / ВикипедиЯ. Свободная энциклопедия. URL: https://ru.wikipedia.org/wiki/\%D0\%9E\%D1\% 80\%D0\%B5\%D0\%B3\%D0\%BE\%D0\%BD\%D1\%81\%D0\%BA\%D0\%B8\%D0\%B9_\%D0\%BF\%D1\%83\%D1\%82\%D1\%8C (дата обращения: 11.09.2021).

14. Первопроходчество. Глава 5. Русские промышленники на Аляске в конце XVIII в. Начало деятельности А.А.Баранова / Военная литература. URL: http://militera.lib.ru/explo/ira/1_05.html (дата обращения: 20.08.2021).

15. Пересечение Александром Макензи Северной Америки/открытие реки Маккензи / Экспедиции и находки. 22.08.2016. URL: https://www.liveinternet.ru/users/stewardess0202/post396736078 (дата обращения: 24.07.2021).

16. Подробная карта Калифорнии - Планетолог.ру / douala.ru. URL: https://yandex.ru/images/search?pos=6\&img url=https\%3A\%2F\%2Fsprtqa.b-cdn.net\%2Fdownload\%2F2ff4c4191252639a90aaec5da85c1c50_i-3122.jpg\&text= \%D0\%B2\%D0\%B5\%D1\%80\%D1\%85\%D0\%BD\%D1\%8F\%D1\%8F\%20\%D0\%BA\%D0\%B0\%D0\%BB\%D0\%B8\%D1\%84 \%D0\%BE\%D1\%80\%D0\%BD\%D0\%B8\%D0\%BA\%D0\%B0\%20\%D0\%BD\%D0\%B0\%20\%D0\%BA\%D0\%B0\%D1\%80\%D 1\%82\%D0\%B5\&lr=213\&rpt=simage \&source=wiz (дата обращения: 29.08.2021).

17. Принц Джордж, Британская Колумбия - Prince George, British Columbia / Википедия. URL: https://ru.abcdef. wiki/wiki/Prince_George,_British_Columbia (дата обращения: 01.09.2021).

18. Северо-Западная компания / Википедия. URL: https://ru.wikipedia.org/wiki/\%D0\%A1\%D0\%B5\%D0\%B2\%D0\% B5\%D1\%80\%D0\%BE-\%D0\%97\%D0\%B0\%D0\%BF\%D0\%B0\%D0\%B4\%D0\%BD\%D0\%B0\%D1\%8F \%D0\%BA\%D0\%B E\%D0\%BC\%D0\%BF\%D0\%B0\%D0\%BD\%D0\%B8\%D1\%8F (дата обращения: 12.09.2021).

19. Селиванова Л. США, город Сан-Франциско: описание города, история, фото / FB. 13.10.2018. URL: https:// fb.ru/article/430729/ssha-gorod-san-frantsisko-opisanie-goroda-istoriya-foto (дата обращения: 08.08.2021).

20. Текст книги «Исследование о природе и причинах богатства народов» / iknigi.net. У нас есть все книги. URL: https://iknigi.net/avtor-adam-smit/119012-issledovanie-o-prirode-i-prichinah-bogatstva-narodov-adam-smit/ read/page-61.html (дата обращения: 22.05.2021).

21. Тихоокеанская меховая компания/ru.knowledgr.com.Новые знания!.URL:http://ru.knowledgr.com/00336998/ PacificFurCompany (дата обращения: 14.09.2021).

22. Утрехтский мир / GUFO.ME. Советская историческая энциклопедия. URL: https://gufo.me/dict/history_encycl opedia/\%D0\%A3\%D0\%A2\%D0\%A0\%D0\%95\%D0\%A5\%D0\%A2\%D0\%A1\%D0\%9A\%D0\%98\%D0\%99_\%D0\%9C\%D0 \%98\%D0\%А0 (дата обращения: 06.09.2021).

23. Форт Астория - Fort Astoria / Википедия. URL: https://ru.abcdef.wiki/wiki/Fort_Astoria (дата обращения: 09.08.2021)

24. Форт-Гуд-Хоуп / Википедия. URL: https://translate.yandex.ru/translate?lang=en-ru\&url=https\%3A\%2F\%2Fen. wikipedia.org\%2Fwiki\%2FFort_Good_Hope\&view=c (дата обращения: 13.09.2021). 
25. Форт Сент-Джеймс - Fort St.James / Ow. URL: https://ru.abcdef.wiki/wiki/Fort_St._James (дата обращения: 28.08.2021).

26. Форт-Уильям, Онтарио - Fort William, Ontario/ Википедия.URL: https://wikichi.ru/wiki/Fort_William,_Ontario (дата обращения: 12.09.2021).

27. Форт Фрейзер, Британская Колумбия - Fort Fraser, British Columbia Форт Фрейзер, Британская Колумбия / Ow. URL: https://ru.abcdef.wiki/wiki/Fort_Fraser,_British_Columbia (дата обращения: 28.08.2021).

28. Форт Чипевян - Fort Chipewyan / Википедия. URL: https://wiki2.wiki/wiki/Fort_Chipewyan (дата обращения: 12.09.2021).

29. Фрейзер, Саймон / Википедия. URL: https://ru.wikipedia.org/wiki/\%D0\%A4\%D1\%80\%D0\%B5\%D0\%B9\%D0\%B7 \%D0\%B5\%D1\%80,_D0\%A1\%D0\%B0\%D0\%B9\%D0\%BC\%D0\%BE\%D0\%BD (дата обращения: 14.09.2021).

30. Hudson's Hope - Hudson’s Норе / Википедия. URL: https://ru.wikichi.ru/wiki/Hudson\%27s_Норе (дата обращения: 14.09.2021). 